\title{
CHANGE OF ECOLOGIC FARM AREAS AND CULTIVATED CULTURES WITHIN THE TERRITORY OF LITHUANIA IN 2010-2014
}

\author{
Laima ČESONIENĖ, Institute of Environment and Ecology, Faculty of Forest Science and Ecology, Aleksandras Stulginskis \\ University, Studentu g. 11, LT-53361 Akademija, Kauno raj., laima.cesoniene@asu.lt \\ Daiva ŠILEIKIENÉ, Institute of Environment and Ecology, Faculty of Forest Science and Ecology, Aleksandras Stulginskis \\ University, Studentų g. 11, LT-53361 Akademija, Kauno raj., daiva.sileikiene@asu.lt (corresponding author) \\ Laura EIGIRDAIT É, Institute of Environment and Ecology, Faculty of Forest Science and Ecology, Aleksandras Stulginskis \\ University, Studentų g. 11, LT-53361 Akademija, Kauno raj., lauraeigirdaite@ gmail.com
}

\begin{abstract}
Research objective is to evaluate the change of ecological farm areas and cultivated cultures within the territory of Lithuania within the period from 2010 to 2014. In 2010-2014 the data from certification institutions (databases) were used for the purpose of evaluation of change of ecological farm areas, which provide all ecological farm areas declared and certified in Lithuania wi thin the whole reported period and agricultural plants cultivated on the areas within the set period. ArcGIS software was used for demonstration of layout of ecological farm areas within the territory of Lithuania. It was established that the major areas of ecological farms analysed within the period were located in the North-East of Lithuania, less areas in the Northern and Southern parts of middle Lithuania. During the whole period the major planted acreage of the ecological farms was taken by meadows, pastures, perennial grass; these cultures annually made almost a half of the declared planted acreage. Less declared planted acreage of the ecological farms within the research period was taken by root plants and vegetables; area planted with the cultures us ually made 1 per cent from all declared planted acreage of the ecological farms. Strong correlation exists between the areas of ecological farms and pastures $(r=0.70$, when $p=0.0001)$, complex agriculture $(r=0.76$, when $p=0.0001)$, transition forest stage and bushes $(\mathrm{r}=0.85$, when $\mathrm{p}=0,0001)$, broad-leaved forests $(\mathrm{r}=0.84$, when $\mathrm{p}=0.0001)$, needle-leaved forests $(\mathrm{r}=0.72$, when $\mathrm{p}=0.0001)$ and mixed forests $(r=0.84$, when $\mathrm{p}=0.0001)$. Weak correlation exists between ecological farm area and agricultural areas with natural plant insertions $(\mathrm{r}=0.47$, when $\mathrm{p}=0.0001)$.
\end{abstract}

Keywords: agricultural plants, acreage, ecological farm.

\section{INTRODUCTION}

People all over the world pay more attention to sparing and ecological farming. We observe people's desire to live in clean and healthy environment, eat healthy food, high-quality food products, therefore the demand of ecological products and areas of ecological farming annually increase all over the world.

In 2008 the certified ecologic farm areas achieved $35.1 \mathrm{mln}$ ha, and by 9 per cents exceed the indices of 2007. The major certified farm area - in the group of Oceania countries - 35 per cents, in Europe and South America - by 23, in Asia - 9, in North America and Africa respectively - 7 and 3 per cents. Comparing with 2007, most increased ecological production area in South America - 1.65, in Europe - $0.5 \mathrm{mln}$ ha.

Faster increase of ecological farm areas was hindered because ecological agriculture had to be developed in clean environment only (Pekarskas et al., 2006; Pekarskas et al., 2007), the amount of products is much smaller than during intensive agricultural production, because use of mineral fertilizers in ecological farming is strictly prohibited. Wishing to ensure required content of nutrient substances in ecological production farms, the main means are fertilization with muck, compost, green fertilizers and various mineral materials of natural origin, and the special attention is paid to selection of seed rotation (great perennial grass and pasture areas are compulsory comparing with other cultures planted in the farm) (Mažvila et al. 1992; Gransted 1995; Niggli et al. 2009; Pekarskas, 2008).

In 2008 the major part of all ecological agriculture area all over the world made pastures -22 mln ha (62.7 per cents), planted acreage $-8.2 \mathrm{mln}$ ha. Pastures (95 per cents) dominated in the group of Oceania countries, plough land (42 per cents) and pastures (47 per cents) - in Europe, plough land (33 per cents) - in North America.

Paper objective and object - to evaluate the change of ecological farm areas and cultivated cultures within the territory of Lithuania within the period from 2010 to 2014.

Copyright (C) 2015 The Authors. Published by Aleksandras Stulginskis University. This is an open-access article distributed under the terms of the Creative Commons Attribution License (CC-BY 4.0), which permits unrestricted use, distribution, and reproduction in any medium, provided the original author and source are credited. 


\section{RESEARCH METHODS}

In 2010-2014 the data from certification institutions (databases) were used for the purpose of evaluation of change of ecological farm areas, which provide all ecological farm areas declared and certified in Lithuania within the whole reported period and agricultural plants cultivated on the areas within the set period.

ArcGIS software was used for demonstration of layout of ecological farm areas within the territory of Lithuania.

Microsoft Excel 2010 software was used for data analysis and their graphical demonstration.

Pearson correlation coefficient was used for determination of dependence on change of ecological farm areas located in basins of rivers referred to Nemunas river basin region.

\section{RESULTS AND DISCUSSION}

After the analysis of changes of ecological farm areas within the territory of the Republic of Lithuania in 2010-2014 it was established that the major ecological farm areas within the whole reported period were located in the North-East of Lithuania, minor - in the northern and southern parts of middle Lithuania (Figure 2, 3, 4, 5, 6).

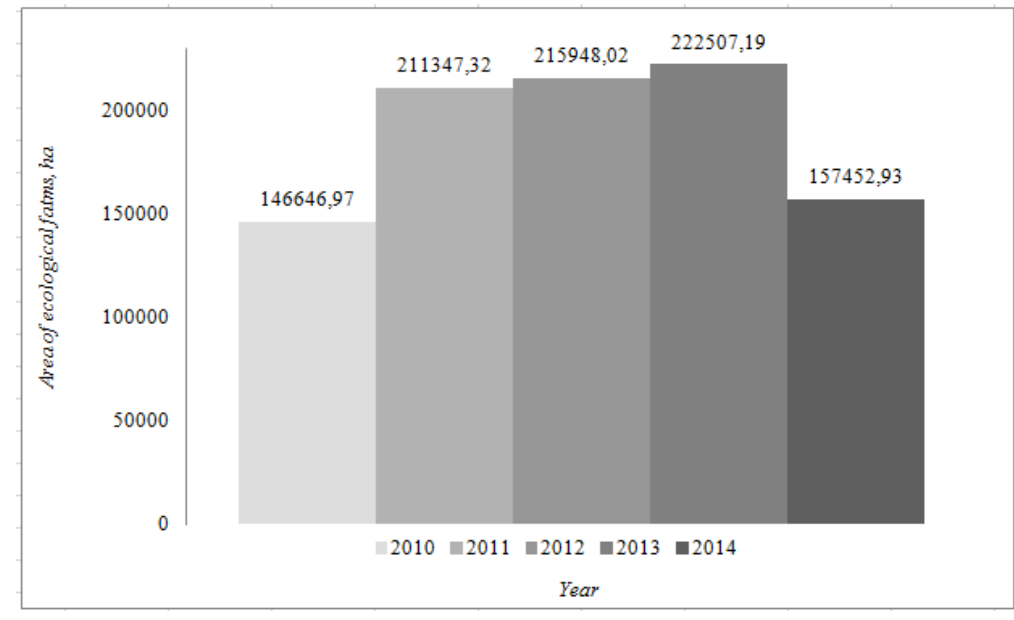

Figure 1. The areas of the ecological farms at 2010-2014, ha

In 2010 the area of the certified ecological farms in Lithuania reached 146646.97 ha, in $2011-211347.32$ ha, in 2012 - 215948.02 ha, in 2013 - 222507.19 ha, and in 2014 the area of the certified ecological farms in Lithuania reached 157452.93 ha (Figure 1).

Therefore, from 2010 to 2013 there was great increase of ecological farm areas within the territory of Lithuania. However in 2014 this area decreased almost to the same size as it was at the beginning of the reported period in 2010.

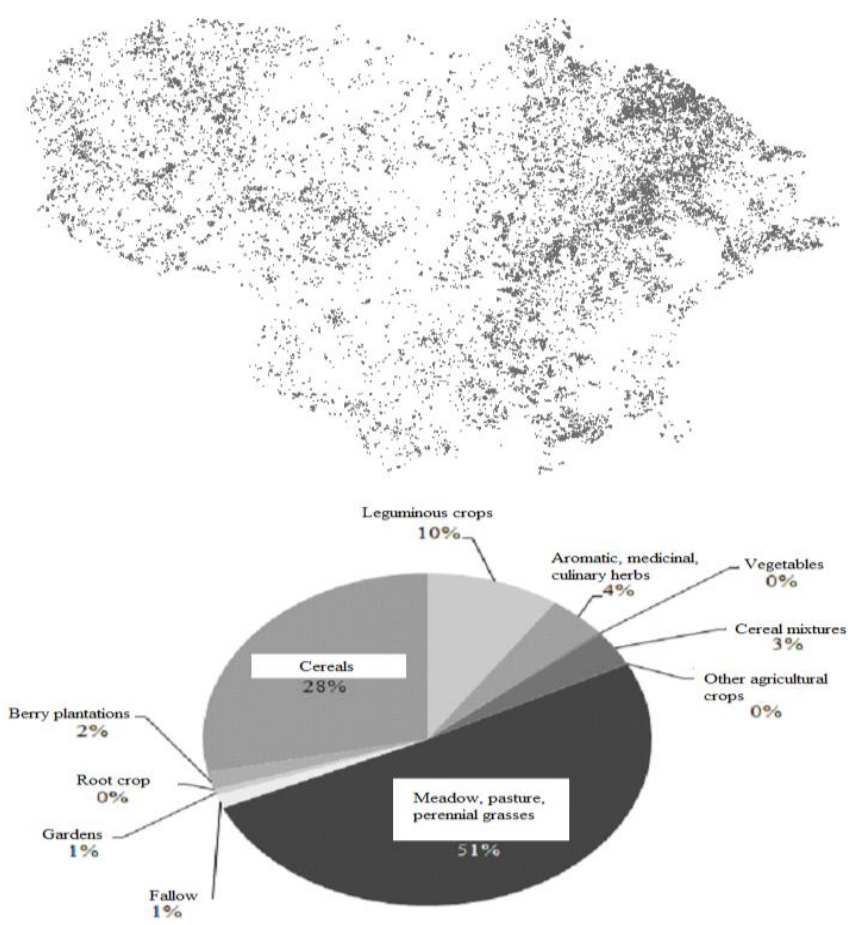

Figure 2. The areas of the organic farms and cropes cultivated in them changes in the teritory of Lithuania at 2010 
In 2010 the major planted acreage of the ecological farms- 51 per cents was taken by meadows, pastures and perennial grass, 28 per cents - by crops, 10 per cents - by leguminous crops, 4 per cents - by aromatic, medical and spicy plants, 3 per cents - by crop mixture, 2 per cents - by berry-bearing plants, 1 per cent - by gardens, fallow, minor declared planted acreage of the ecological farms in 2010 was taken by root crops and vegetables (it reached almost 1 per cent) (Figure 2).

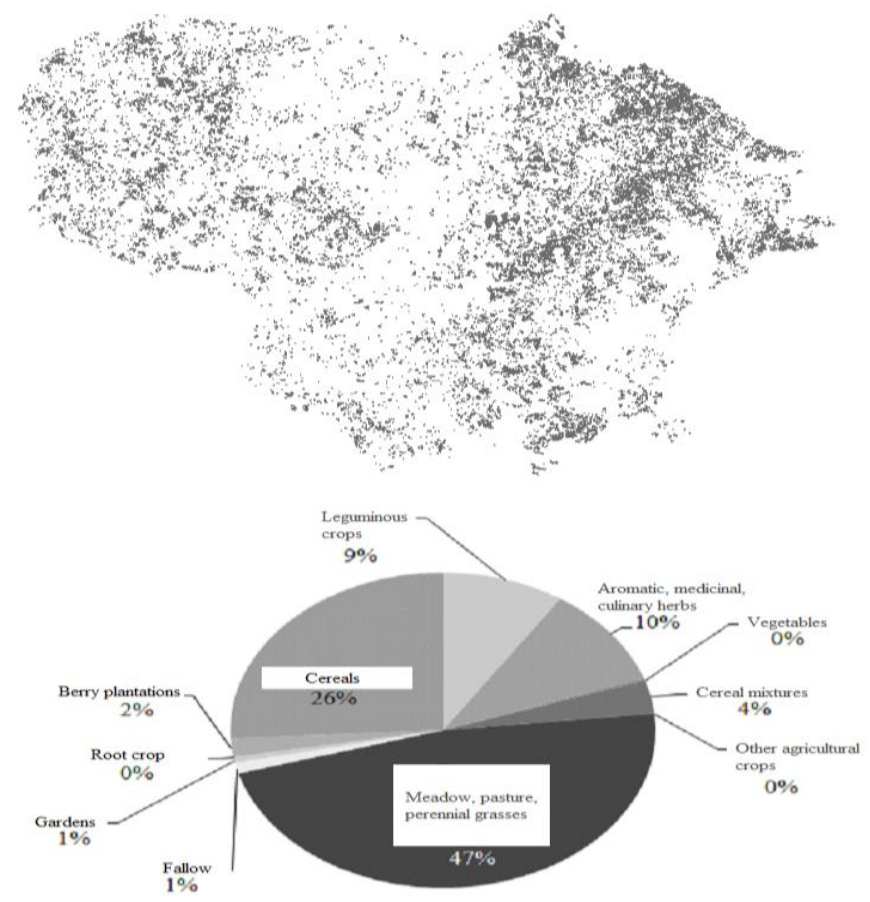

Figure 3. The areas of the organic farms and cropes cultivated in them changes in the teritory of Lithuania at 2011

In 2011 the major planted acreage of the ecological farms was taken by meadows, pastures and perennial grass -47 per cents, 26 per cents - crops, 9 per cents - leguminous crops, 10 per cents - aromatic, medical and spicy plants, 4 per cents - crop mixture, 2 per cents - berry-bearing plants, 1 per cent - gardens, fallow, minor declared planted acreage of the ecological farms was taken by root crops and vegetables (Figure 3).
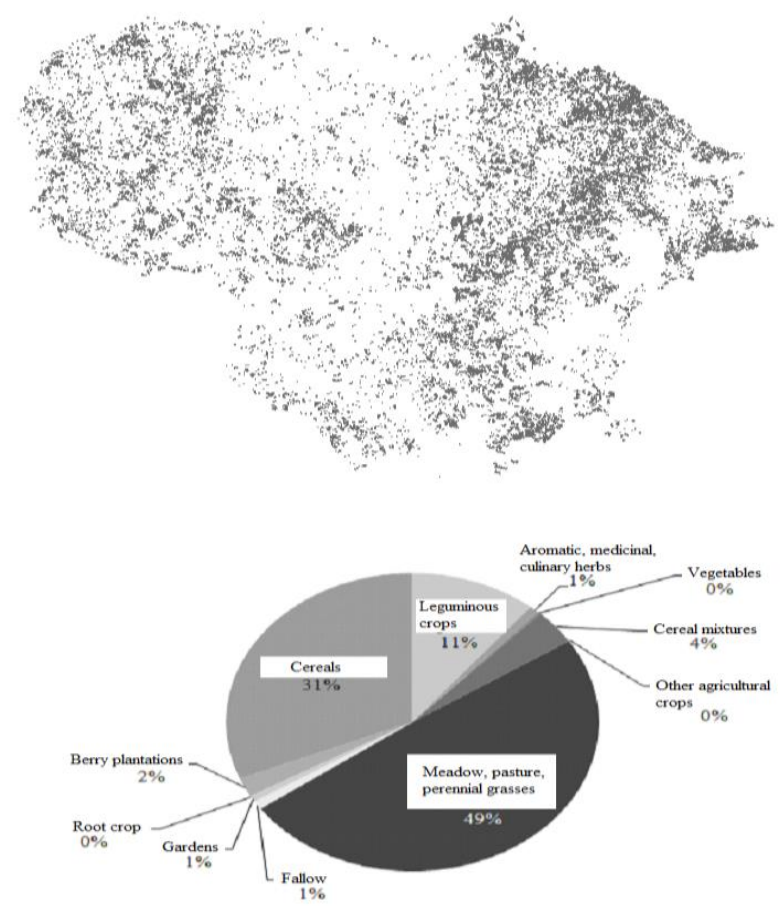

Figure 4. The areas of the organic farms and cropes cultivated in them changes in the teritory of Lithuania at 2012 
In 2012 the major planted acreage of the ecological farms was taken by meadows, pastures and perennial grass - 49 per cents, 31 per cents - crops, 11 per cents - leguminous crops, 4 per cents - crop mixture, 2 per cents - berrybearing plants, 1 per cent - gardens, fallow, minor declared planted acreage of the ecological farms in 2012 was taken by root crops and vegetables (Figure 4).

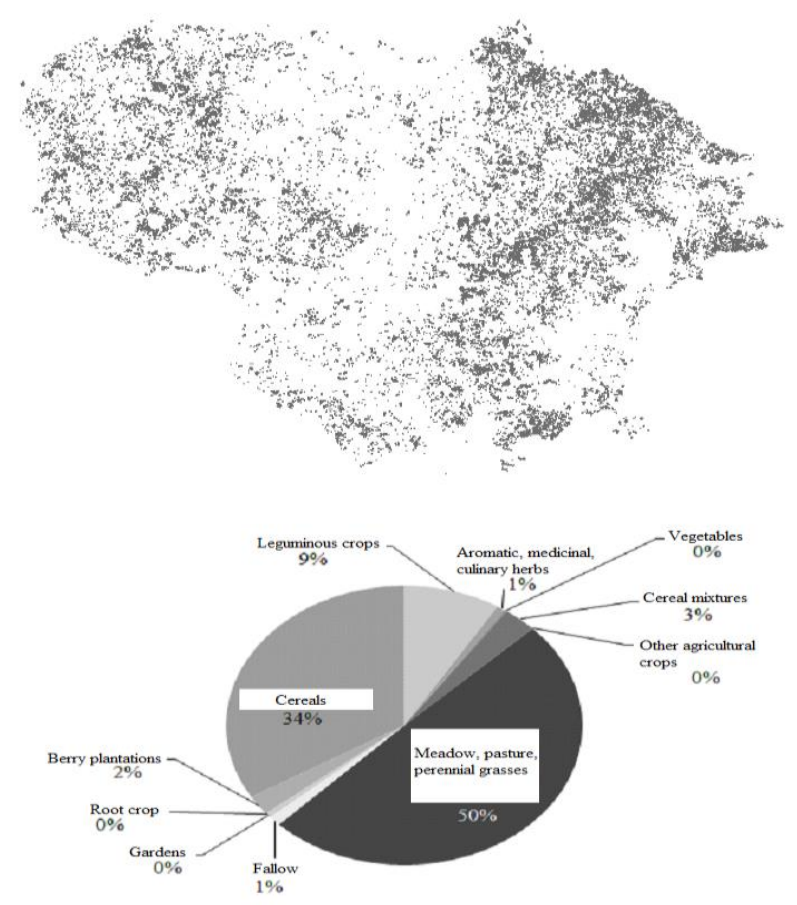

Figure 5. The areas of the organic farms and cropes cultivated in them changes in the teritory of Lithuania at 2013

In 2013 the major planted acreage of the ecological farms was taken by meadows, pastures and perennial grass - 50 per cents, 34 per cents - crops, 9 per cents - leguminous crops, 3 per cents - crop mixture, 2 per cents - berry-bearing plants, 1 per cent - gardens, fallow, aromatic, medical and spicy plants, minor declared planted acreage of the ecological farms in 2013 was taken by root crops and vegetables (Fugure 5).
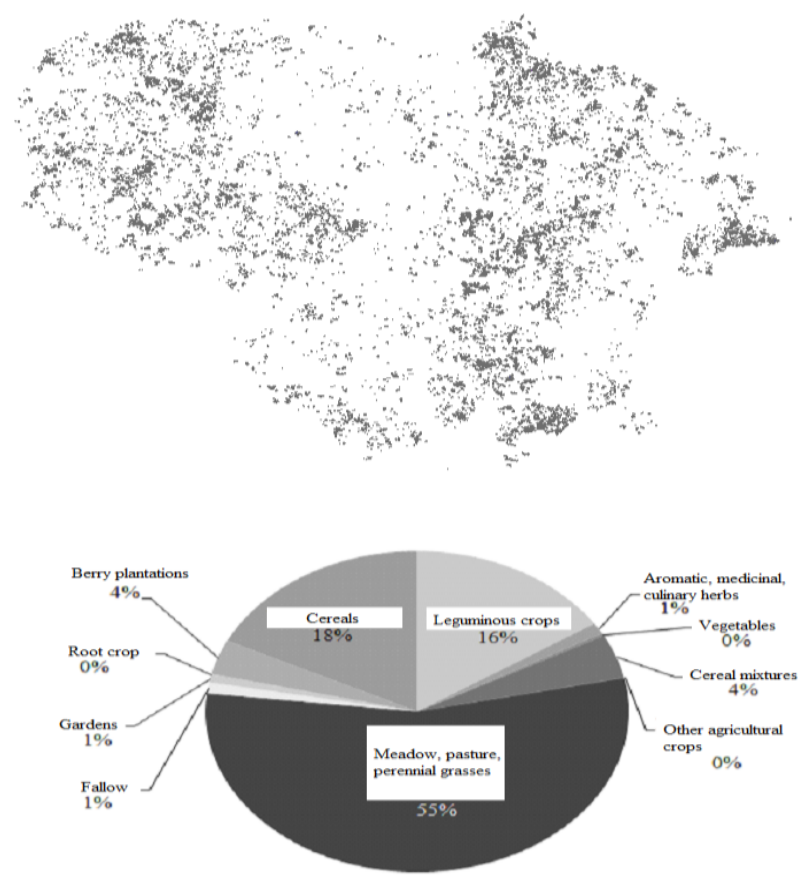

Figure 6. The areas of the organic farms and cropes cultivated in them changes in the teritory of Lithuania at 2014

In 2014 the major planted acreage of the ecological farms was taken by meadows, pastures and perennial grass - 55 per cents, 18 per cents - crops, 16 per cents - leguminous crops, - berry-bearing plants, crop mixture took 4 per 
cents of planted acreage, 1 per cent - gardens, fallow, aromatic, medical and spicy plants, minor declared planted acreage of the ecological farms in 2014 was taken by root crops and vegetables (Figure 6).

Therefore, during the reported period the major planted acreage of ecological farms was taken by meadows, pastures, perennial grass, there plants annually took almost half of the declared planted acreage (47-55 per cents).

During the reported period the minor declared planted acreage of ecological farms was taken by root crops and vegetables, the taken area reached less than 1 per cent of all declared planted acreage of ecological farms.

In 2010-2014 crops took from 18 to 34 per cents of all declared planted acreage of ecological farms. Leguminous crops took only $9-16$ per cents.

\section{ANALYSIS OF CHANGES OF ECOLOGICAL FARM AREAS, LOCATED IN BASINS OF RIVERS REFERRED TO NEMUNAS RIVER BASIN REGION}

Whereas data extract is great enough $(n=21)$, we shall use Pearson coefficient to determine the dependence of change of ecological farm areas, located in in basins of rivers referred to Nemunas river basin region (Table 1).

Table 1. Matrix of factor change of ecological farm areas, located in basins of rivers referred to Nemunas river basin region

\begin{tabular}{|c|c|c|c|c|c|c|c|c|c|c|c|c|}
\hline & 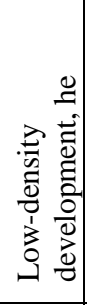 & 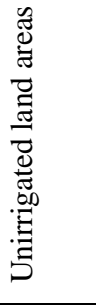 & 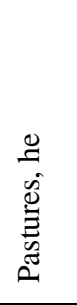 & 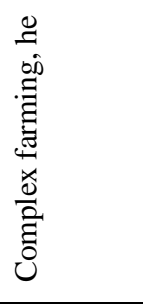 & 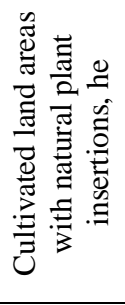 & 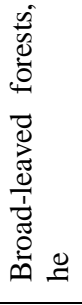 & 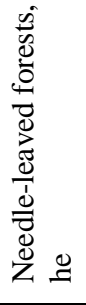 & 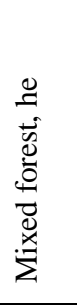 & 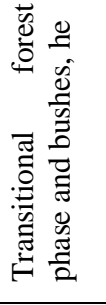 & 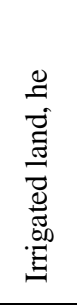 & 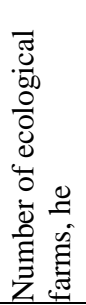 & 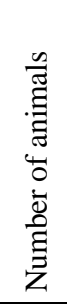 \\
\hline $\begin{array}{l}\text { Areas of } \\
\text { organic } \\
\text { farming, he }\end{array}$ & 0,62 & 0,69 & 0,70 & $\begin{array}{c}r=0,76 \\
p=0.001\end{array}$ & 0,47 & 0,84 & 0,72 & 0,84 & 0,85 & 0,65 & 0,61 & 0,55 \\
\hline
\end{tabular}

According to Pearson correlation test it was established that strong correlation $(0.7 \leq|\mathrm{r}| \leq 0.9)$, when $\mathrm{p}<\alpha$, exists between ecological farm areas and all pastures, located in basins of rivers referred to Nemunas river basin region $(r=0.70$, when $p=0.0001)$, complex farming $(r=0.76$, when $p=0.0001)$, transitional forest phase and bushes $(r=0.85$, when $p=0.0001)$, broad-leaved forests $(r=0.84$, when $p=0.0001)$, needle-leaved forests $(r=0.72$, when $p=0.0001)$ and mixed forest $(\mathrm{r}=0.84$, when $\mathrm{p}=0.0001)$ areas. Ecological farm area located in in basins of rivers referred to Nemunas river basin region increases with increase of pastures, transitional forest phase and bushes, broad-leaved forests, needleleaved forests and mixed forest areas.

According to Pearson correlation test it was established that medium strength correlation $(0.5 \leq|\mathrm{r}| \leq 0.7)$, when $\mathrm{p}<\alpha$, exists between ecological farm areas, located in basins of rivers referred to Nemunas river basin region and low-density development $(r=0.62$, when $\mathrm{p}=0.0001)$, unirrigated land areas $(\mathrm{r}=0.69$, when $\mathrm{p}=0.0001)$, irrigated land areas $(r=0.65$, when $\mathrm{p}=0.0001)$ number of animals (hereinafter referred to as $\mathrm{SG})(\mathrm{r}=0.55$, when $\mathrm{p}=0.0001)$ and number of ecological farms $(r=0.61$, when $p=0.0001)$. Ecological farm area located in in basins of rivers referred to Nemunas river basin region increases with increase of values of indices.

According to Pearson correlation test it was established that weak correlation $(0.2 \leq|\mathrm{r}| \leq 0.5)$, when $\mathrm{p}<\alpha$, exists tarp between ecological farm areas and cultivated land areas with natural plant insertions $(r=0.47$, when $\mathrm{p}=0.0001)$.

\section{CONCLUSIONS}

1. It was established that the major areas of ecological farms analysed within the period were located in the North-East of Lithuania, less areas in the Northern and Southern parts of the middle of Lithuania.

2. From 2010 to 2013 there was great increase of ecological farm areas within the territory of Lithuania. However in 2014 this area decreased almost to the same size as it was at the beginning of the reported period in 2010.

3. During the whole period the major planted acreage of the ecological farms was taken by meadows, pastures, perennial grass; these cultures annually made almost a half of the declared planted acreage ( $47-55$ per cents).

4. Less declared planted acreage of the ecological farms within the research period was taken by root plants and vegetables; area planted with the cultures usually made 1 per cent from all declared planted acreage of the ecological farms.

5. Strong correlation exists between the areas of ecological farms and pastures $(r=0.70$, when $\mathrm{p}=0.0001)$, complex agriculture $(r=0.76$, when $p=0.0001)$, transition forest stage and bushes $(r=0.85$, when $p=0,0001)$, broad-leaved forests $(r=0.84$, when $\mathrm{p}=0.0001)$, needle-leaved forests $(\mathrm{r}=0.72$, when $\mathrm{p}=0.0001)$ and mixed forests $(r=0.84$, when $\mathrm{p}=0.0001)$.

6. Medium strength correlation exists between ecological farm areas, located in basins of rivers referred to Nemunas river basin region and low-density development $(\mathrm{r}=0.62$, when $\mathrm{p}=0.0001)$, unirrigated land areas $(\mathrm{r}=0.69$, when $\mathrm{p}$ $=0.0001)$, irrigated land areas $(r=0.65$, when $\mathrm{p}=0.0001)$ number of animals (hereinafter referred to as $\mathrm{SG})(\mathrm{r}=0.55$, when $\mathrm{p}=0.0001)$ and number of ecological farms $(\mathrm{r}=0.61$, when $\mathrm{p}=0.0001)$. 
7. Weak correlation exists between ecological farm area and agricultural areas with natural plant insertions $(\mathrm{r}=0.47$, when $\mathrm{p}=0.0001$ ).

\section{RREFERENCES}

1. Mažvila, J., Vaišvila, Z., Radžiūnas, V. 1992. Ilgalaikio tręšimo mineralinèmis trą̌somis ịtaka derliui, dirvožemio agrocheminèms savybėms, maisto medžiagų išplovimui. Antropogeninių veiksnių ịtaka dirvožemio derlingumui, p. 52-57. (In Lithuanian)

2. Granstedt, A. 1995. Studies of the flow, supply and losses of nitrogen and other nutrient in conventional and ecological systems in Sweden. Biological Agriculture \& Horticulture, Vol. 11, Iss. 1-4, pp. 51-67. http://dx.doi.org/10.1080/01448765.1995.9754693

3. Niggli, U., Fliessbach, A., Hepperly, P., Scialabba, N. 2009. Low Greenhouse Gas Agriculture: Mitigation and Adaptation Potential of Sustainable Farming Systems. FAO (Rev. 2-2009).

4. Pekarskas, J. 2008. Trę̌̌imas ekologinės gamybos ūkiuose. Kaunas: LŽŪU, 188 p. (In Lithuanian)

5. Pekarskas, J., Kazlienė, O., Gavenauskas, A. 2006. Ekologinio ūkininkavimo plètra ir perspektyvos Lietuvoje. Vadyba, Nr. 2(9), p. 169-173. (In Lithuanian)

6. Pekarskas, J., Kazlienè, O., Gavenauskas, A. 2007. Ekologinis ūkininkavimas Lietuvoje. Vadyba, Nr. 2(11), p. 197-200. (In Lithuanian) 